\title{
Milk protein fractions strongly affect the patterns of coagulation, curd firming, and syneresis
}

\author{
Nicolò Amalfitano, ${ }^{1}$ Claudio Cipolat-Gotet, ${ }^{2}$ Alessio Cecchinato, ${ }^{1}$ Massimo Malacarne,${ }^{2}$ Andrea Summer, ${ }^{2 *}$ \\ and Giovanni Bittante ${ }^{1}$ \\ ${ }^{1}$ Department of Agronomy, Food, Natural Resources, Animals and Environment (DAFNAE), University of Padova (Padua), \\ 35020 Legnaro (PD), Italy \\ ${ }^{2}$ Department of Veterinary Science, University of Parma, 43126 Parma, Italy
}

\section{ABSTRACT}

The aim of this study was to assess the role of milk protein fractions in the coagulation, curd firming, and syneresis of bovine milk. Analyses were performed on 1,271 individual milk samples from Brown Swiss cows reared in 85 herds classified into 4 types of farming systems, from the very traditional (tied cows, feed manually distributed, summer highland pasture) to the most modern (loose cows, use of total mixed rations with or without silage). Fractions $\alpha_{\mathrm{S}_{1}}$-casein $(\mathrm{CN}), \alpha_{\mathrm{S}_{2}} \mathrm{CN}$, $\beta$-CN, $\kappa$-CN, $\beta$-lactoglobulin (LG), and $\alpha$-lactalbumin (LA) and genotypes at CSN2, CSN3, and $B L G$ were obtained by reversed-phase HPLC. The following milk coagulation properties were measured with a lactodynamograph, with the testing time extended to $60 \mathrm{~min}$ : rennet coagulation time (RCT, min), curd firming time (min), and curd firmness at 30 and $45 \mathrm{~min}$ (mm). All the curd firmness measures recorded over time (total of 240 observations/sample) were used in a 4-parameter nonlinear model to obtain parameters of coagulation, curd firming, and syneresis: RCT estimated from the equation ( $\mathrm{min})$, asymptotic potential curd firmness $(\mathrm{mm})$, the curd firming and syneresis instant rate constants $(\% / \mathrm{min})$, and the maximum curd firmness value $\left(\mathrm{CF}_{\max }, \mathrm{mm}\right)$ and the time taken to reach it (min). All the aforementioned traits were analyzed with 2 linear mixed models, which tested the effects of the protein fractions expressed in different ways: in the first, quantitative model, each protein fraction was expressed as content in milk; in the second, qualitative model, each protein fraction was expressed as a percentage of total casein content. Besides proteins, additional nuisance parameters were herd (included as a random

Received August 9, 2018.

Accepted December 14, 2018.

*Corresponding author: andrea.summer@unipr.it effect), daily milk production (only for the quantitative model), casein content (only for the qualitative model), dairy system, parity, days in milk, the pendulum of the lactodynamograph, and the CSN2, CSN3, and $B L G$ genotypes. Both $\alpha_{\mathrm{S}_{1}} \mathrm{CN}$ and $\beta$-CN showed a clear and favorable effect on $\mathrm{CF}_{\max }$, where the former effect was almost double the latter. Milk coagulation ability was favorably affected by $\kappa-\mathrm{CN}$, which reduced both the RCT and RCT estimated from the equation, increased the curd firming and syneresis instant rate constants, and allowed a higher $\mathrm{CF}_{\max }$ to be reached. In contrast, $\alpha_{\mathrm{S} 2^{-}} \mathrm{CN}$ delayed gelation time and $\beta-\mathrm{LG}$ worsened curd firming, both resulting in a low $\mathrm{CF}_{\max }$. The results of this study suggest that modification of the relative contents of specific protein fractions can have an enormous effect on the technological behavior of bovine milk.

Key words: casein, whey protein, lactoglobulin, cheese-making ability, milk clotting

\section{INTRODUCTION}

Milk coagulation and curd firming processes have been widely studied in recent decades, and milk protein fractions have been identified as the principal actors in these processes (Guinee, 2003; Bittante et al., 2012). The 4 main caseins $\left(\alpha_{\mathrm{S1}^{-}}, \alpha_{\mathrm{S}^{-}}, \beta_{-}\right.$, and $\left.\kappa^{-} \mathrm{CN}\right)$ are organized in globular structures recognized as casein micelles. These micelles, which are stabilized on the surface by the C-terminal region of $\kappa-\mathrm{CN}$, are the substrate of milk rennet coagulation (Fox, 2003; Caroli et al., 2009), a process that begins with hydrolysis of $\kappa-\mathrm{CN}$ by the chymosin of rennet. When about $80 \%$ of the $\kappa-\mathrm{CN}$ is hydrolyzed, the resulting paracasein micelles start to aggregate in the presence of ionic calcium (coagulation) and form a reticulum, which entraps the soluble phase and fat globules (Guinee, 2003). The number of secondary interactions within the curd increases over time, leading to its contraction (syneresis) and partial expulsion of whey. 
For many decades, lactodynamography has been the most widely used method to evaluate these processes (Annibaldi et al., 1977; McMahon and Brown, 1982). The output of the analysis is a diagram of curd firmness versus time $\left(\mathbf{C F}_{\mathbf{t}}\right)$. From this diagram, 3 single-point milk coagulation properties (MCP) are traditionally obtained: (1) the time from rennet addition to the beginning of gelation (rennet coagulation time, RCT, min), (2) the time from coagulation to a curd firmness of $20 \mathrm{~mm}\left(\mathbf{k}_{\mathbf{2 0}}, \mathrm{min}\right)$, and (3) curd firmness 30 min after rennet addition $\left(\mathbf{a}_{\mathbf{3 0}}, \mathrm{mm}\right)$.

However, according to Bittante (2011), traditional MCP have various limitations, such as low repeatability and the existence of noncoagulating samples, which prevent the coagulation process from being described completely. To overcome these limitations, Bittante et al. (2013) proposed the application of a 4-parameter model to the multiple measures per minute $\left(\mathrm{CF}_{\mathrm{t}}\right)$ obtained by modern lactodynamographs. They also extended the test beyond $30 \mathrm{~min}$ to include the information from late-coagulating samples and to record the syneresis phase. The coagulation, curd firming, and syneresis parameters obtained would be more informative and provide a better understanding of the coagulation process.

No information is available on the effect of the milk protein profile on model parameters of coagulation, curd firming, and syneresis processes. Several studies have dealt, in particular, with the effects of the genetic variants of different protein fractions on single-point coagulation and curd firming traits, as reviewed by Bittante et al. (2012). Researchers have found that the presence of different variants in milk could affect the protein composition and the behavior of the proteins themselves during gelation, thereby influencing the entire cheese-making process. In fact, they have shown that the $\mathrm{B}$ variants of $\beta-\mathrm{CN}, \kappa-\mathrm{CN}$, and $\beta-\mathrm{LG}$ favorably affect $\mathrm{MCP}$ by reducing coagulation time and improving curd firmness. On the other hand, other variants, such as $\kappa-\mathrm{CN} \mathrm{A}$ and $\mathrm{E}$, have a negative effect on coagulation (Schaar et al., 1985; Marziali and Ng-Kwai-Hang, 1986; Heck et al., 2009; Jensen et al., 2012a). However, fewer studies have looked at the effect of the concentrations of different protein fractions in milk (Jõudu et al., 2008). Even fewer have dealt with both the amount and the genotype of each protein fraction to obtain an unbiased estimation of both of these effects on milk technological traits (Wedholm et al., 2006; Bonfatti et al., 2010).

The aim of our research was to study the influence of individual milk protein fractions, expressed as their content in milk or as a proportion of total casein content, on traditional single-point coagulation properties and on curd firming over time $\left(\mathrm{CF}_{\mathrm{t}}\right)$ model parameters independently of the genotype of the main protein fractions.

\section{MATERIALS AND METHODS}

\section{Dairy Systems, Animals, and Sample Collection}

This work is part of the multidisciplinary project "Cowability-Cowplus," which has the aim of evaluating the cheese-making aptitude of Brown Swiss cows reared in different dairy systems and includes a parallel study on the effects of protein fractions on cheese yield and the recovery of milk nutrients in cheese (Cipolat-Gotet et al., 2013, 2018). Individual milk samples were collected from 1,271 Brown Swiss cows on 85 herds (maximum 15 cows/herd) reared in Trento Province (Northeast Italy). The herds were classified into 4 farming systems: (1) small traditional farms with tied cows, hay, and compound feed distributed manually and often with summer transhumance to highland pasture; (2) modern dairy farms with loose cows, milking parlors, and forages and concentrates distributed separately; (3) modern dairy farms with TMR, including silage; and (4) modern dairy farms with silage-free TMR. The various dairy systems and their effects on MCP and $\mathrm{CF}_{\mathrm{t}}$ parameters were described in a previous study (Bittante et al., 2015) in which more favorable coagulation properties were observed on the traditional farms compared with the other modern and intensive farming systems.

Milk samples were collected during the evening milking and immediately refrigerated at $4^{\circ} \mathrm{C}$. Sampling, refrigeration, transport, and storage were described in detail by Cipolat-Gotet et al. (2012). The samples were divided into 2 aliquots: the first $(50 \mathrm{~mL})$ was transported to the Milk Quality Laboratory of the Trento Breeders Association (Trento, Italy) for milk composition analysis, and the second ( $2 \mathrm{~L}$ ) was taken to the Milk Laboratory of the Department of Agronomy, Food, Natural Resources, Animals and Environment of the University of Padova (Legnaro, Padova, Italy). The latter subsample was used to measure MCP with a Formagraph (Foss Electric A/S, Hillerød, Denmark) within $20 \mathrm{~h}$ of collection and to quantify protein fractions by HPLC.

\section{Milk Composition Analyses}

Gross Composition Traits. The protein, casein, fat, and lactose percentages in milk were estimated using a MilkoScan FT6000 (Foss Electric A/S) calibrated according to the following reference methods: fat (ISO, 2010; ISO1211/IDF 1; gravimetric method, Röse-Gottli- 
eb), protein (ISO, 2014; ISO 8968-1/IDF 20-1; titrimetric method, Kjeldahl), casein (ISO, 2004; ISO 17997-1/ IDF 29; titrimetric method, Kjeldahl), and lactose (ISO, 2002; ISO 5765-1/IDF 79-1; enzymatic method). A Fossomatic FC counter (Foss Electric A/S) was used to evaluate the SCC, which was then converted into an SCS using the formula SCS $=\log _{2}(\mathrm{SCC} / 100,000)+3$. Finally, milk pH was determined with a Crison Basic 25 electrode (Crison, Barcelona, Spain).

Milk Protein Fractions. From each individual milk subsample $(2 \mathrm{~L})$, a $2-\mathrm{mL}$ aliquot was taken, frozen at $-80^{\circ} \mathrm{C}$, and set aside for identification and quantification of the protein fractions by reversed-phase HPLC. The method used to separate and identify the principal protein fractions $\left(\alpha_{\mathrm{S}^{-}} \mathrm{CN}, \alpha_{\mathrm{S}^{2}} \mathrm{CN}, \beta-\mathrm{CN}, \kappa-\mathrm{CN}\right.$, $\beta-\mathrm{LG}$, and $\alpha-\mathrm{LA})$ is described in detail by Bonfatti et al. (2008). The $\alpha_{\mathrm{S} 1}-\mathrm{CN}$ form with 9 phosphorylated residues (instead of 8 residues) was also identified and indicated as $\boldsymbol{\alpha}_{\mathbf{S} 1}-\mathbf{C N p h}$ (Bonfatti et al., 2011). Briefly, each protein fraction was quantified by a calibration curve prepared with solutions of the individual fraction in increasing concentrations. Commercial protein standards were purchased from Sigma-Aldrich (St. Louis, $\mathrm{MO}$ ), and their purity was checked by electrophoresis

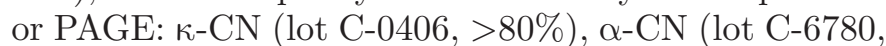
$>70 \%), \beta-\mathrm{CN}($ lot $\mathrm{C}-6905,>90 \%), \alpha-\mathrm{LA}($ lot L-5385 type $\mathrm{I},>85 \%), \beta-\mathrm{LG}_{\mathrm{B}}\left(\right.$ lot $\mathrm{L}-8005,90 \%$ ), and $\beta-\mathrm{LG}_{\mathrm{A}}$ (lot L-7880, >90\%). The resolution of the milk chromatograms allowed the genetic variants of $\beta-\mathrm{CN}\left(\mathrm{A}_{1}\right.$, $\left.\mathrm{A}_{2}, \mathrm{~B}\right), \kappa-\mathrm{CN}(\mathrm{A}, \mathrm{B})$, and $\beta$-LG (A, B) to be identified. The purity of the protein standards and the genetic variants was evaluated following the method of protein separation, purification, and calibration described in detail by Bonfatti et al. (2008). In this population, the genotypes for CSN2 were $\mathrm{A}_{1} \mathrm{~A}_{2}(10.5 \%), \mathrm{A}_{1} \mathrm{~B}(2.2 \%)$, $\mathrm{A}_{2} \mathrm{~A}_{2}(60.4 \%), \mathrm{A}_{2} \mathrm{~B}(25.1 \%)$, and $\mathrm{BB}(1.8 \%)$, whereas the genotypes identified for CSN3 were AA (4.8\%), AB $(36.2 \%)$, and $\mathrm{BB}(59.0 \%)$; the $\mathrm{E}$ variant is generally not found in Brown Swiss cows. The genotypes identified for $B L G$ were AA (10.7\%), $\mathrm{AB}(44.4 \%)$, and $\mathrm{BB}$ $(44.9 \%)$.

\section{Traditional MCP}

A 10-mL aliquot of the 2-L subsample was used for determination of MCP by Formagraph (Foss Electric A/S) according to the method described in detail by Bittante et al. (2015). Only rennet (0.051 IMCU/mL of milk) was added to each sample, and curd firmness was recorded every $15 \mathrm{~s}$ for $60 \mathrm{~min}$ by the instrument, yielding 240 measurements per milk sample, 4 of which were used to determine the traditional single-point MCP parameters $\left[\mathrm{RCT}, \mathrm{k}_{20}, \mathrm{a}_{30}\right.$, and curd firmness 45 min after rennet addition $\left.\left(\mathbf{a}_{45}\right)\right]$.

\section{Modeling Curd Firmness and Syneresis}

Files containing the 240 curd firmness values for each milk sample were retrieved and processed using the 4-parameter mathematic model proposed by Bittante et al. (2013). This model uses all of the information from the 240 points to obtain 4 model parameters of curd firmness for each milk sample as follows:

$$
\mathrm{CF}_{\mathrm{t}}=\mathrm{CF}_{\mathrm{P}} \times\left[1 \times \mathrm{e}^{-\mathrm{k}_{\mathrm{CF}} \times\left(\mathrm{t}-\mathrm{RCT}_{\mathrm{eq}}\right)}\right] \times \mathrm{e}^{-\mathrm{k}_{\mathrm{SR}} \times\left(\mathrm{t}-\mathrm{RCT}_{\mathrm{eq}}\right)},
$$

where $\mathrm{CF}_{\mathrm{t}}$ is the curd firmness $(\mathrm{mm})$ at time $\mathrm{t}, \mathbf{C F}_{\mathbf{P}}$ is the asymptotic potential maximum value of curd firmness at infinite time $(\mathrm{mm}), \mathbf{k}_{\mathbf{C F}}$ is the curd firming instant rate constant $(\% / \mathrm{min}), \mathbf{k}_{\mathbf{S R}}$ is the curd syneresis instant rate constant (\%/min), and $\mathbf{R C T}_{\mathbf{e q}}$ is the RCT estimated by the model (min). The model can also predict the maximum curd firmness estimated by the $\mathrm{CF}_{\mathrm{t}}$ function $\left(\mathbf{C F}_{\max }\right)$ and the time taken to reach this value $\left(\mathbf{t}_{\text {max }}\right)$. To improve repeatability, $\mathrm{CF}_{\mathrm{P}}$ was estimated using a linear regression based on the $\mathrm{CF}_{\max }$ $\left(\mathrm{CF}_{\mathrm{P}}=1.34 \times \mathrm{CF}_{\max }\right)$ according to data recorded by Bittante et al. (2015).

\section{Statistical Analyses}

Traditional single-point $\mathrm{MCP}$ and $\mathrm{CF}_{\mathrm{t}}$ model parameters were analyzed with 2 linear mixed models using the same approach taken by Cipolat-Gotet et al. (2018). The first model (referred to as $\mathbf{M}-\mathbf{g} / \mathbf{L}$ ) included daily milk yield (dMY, $\mathrm{kg} / \mathrm{d})$ and defined the quantitative effect of each protein fraction; the protein fractions were expressed as grams per liter of milk. The second model (referred to as M-\%cas) defined the qualitative effect of protein proportions; dMY was substituted by the total casein content of milk, and the protein fractions were expressed as percentage of the total casein content. Moreover, the milk protein genotypes were included in the models. The aim of this inclusion was to distinguish between the possible confounding effects of the milk protein genotypes and the effects of the quantity of each milk protein fraction on the traits studied. In fact, the aim was not to study them in detail, as the genetic aspects of the protein fractions were already discussed in previous studies (Dadousis et al., 2017, 2018; Pegolo et al., 2018). The M-g/L model was as follows:

$$
\begin{gathered}
\mathrm{y}_{\text {fghijklmnopqrstuv }}=\mu+\text { dairy system }_{f} \\
+\operatorname{herd}_{g}\left(\text { dairy system }_{f}+\mathrm{DIM}_{h}+\text { parity }_{i}+\mathrm{dMY}_{j}\right. \\
+\beta-\mathrm{CN}_{-} \mathrm{GT}_{k}+\kappa-\mathrm{CN}_{-} \mathrm{GT}_{l}+\beta-\mathrm{LG}-\mathrm{GT}_{m}+\alpha_{\mathrm{S}^{-}-\mathrm{CN}_{n}} \\
+\alpha_{\mathrm{S}^{-}} \mathrm{CNph}_{o}+\alpha_{\mathrm{S}^{2}} \mathrm{CN}_{p}+\beta-\mathrm{CN}_{q}+\kappa-\mathrm{CN}_{r}+\alpha-\mathrm{LA}_{s} \\
\quad+\beta-\mathrm{LG}_{t}+\text { pendulum }_{u}+\mathrm{e}_{\text {fghijklmnopqrstuv }},
\end{gathered}
$$


where $\mathrm{y}_{\text {fghijklmnopqrstuv }}$ represents the dependent variables tested with the models $\left(\mathrm{RCT}, \mathrm{k}_{20}, \mathrm{a}_{30}, \mathrm{a}_{45}, \mathrm{RCT}_{\text {eq }}, \mathrm{k}_{\mathrm{CF}}\right.$, $\left.\mathrm{k}_{\mathrm{SR}}, \mathrm{CF}_{\mathrm{P}}, \mathrm{CF}_{\max }, \mathrm{t}_{\max }\right) ; \mu$ is the overall mean; dairy system $_{f}$ is the fixed effect of the fth class of dairy system $(f=1$ to 4$)$; $\operatorname{herd}_{g}$ (dairy system $)_{f}$ is the random effect of the gth herd class within the fth class of dairy system; $\mathrm{DIM}_{h}$ is the fixed effect of the $h$ th 60 -d class of lactation (6 classes); parity $_{i}$ is the fixed effect of the $i$ th class of parity order $(i=1$ to $\geq 5)$; $\mathrm{dMY}_{j}$ is the fixed effect of the $j$ th class of daily milk yield ( 7 classes); casein $_{j}$ is the fixed effect of the $j$ th class of casein content in milk ( 7 classes); $\beta-\mathrm{CN}-\mathrm{GT}_{k}$ is the fixed effect of the $k$ th class of CSN2 genotype identified ( 5 classes: $\left.\mathrm{A}_{1} \mathrm{~A}_{2}, \mathrm{~A}_{1} \mathrm{~B}, \mathrm{~A}_{2} \mathrm{~A}_{2}, \mathrm{~A}_{2} \mathrm{~B}, \mathrm{BB}\right) ; \kappa-\mathrm{CN}-\mathrm{GT}_{l}$ is the fixed effect of the lth class of CSN3 genotype identified (3 classes: AA, AB, BB); $\beta-\mathrm{LG}-\mathrm{GT}_{m}$ is the fixed effect of the $m$ th class of $B L G$ genotype identified (3 classes: $\mathrm{AA}, \mathrm{AB}, \mathrm{BB}) ; \alpha_{\mathrm{S}_{1}}-\mathrm{CN}_{n}$ is the fixed effect of the $n$th class of $\alpha_{\mathrm{S1}^{-}} \mathrm{CN}$ content $(7$ classes; $\mathrm{M}-\mathrm{g} / \mathrm{L}=$ in $\mathrm{g} / \mathrm{L}$ of milk; M-\%cas $=\%$ of milk total casein content); $\alpha_{\mathrm{S} 1}-\mathrm{CNph}_{o}$ is the fixed effect of the oth class of content of $\alpha_{S_{1}}$ CN with one more phosphorylated serine residue (7 classes); $\alpha_{\mathrm{S}_{2}}-\mathrm{CN}_{p}$ is the fixed effect of the $p$ th class of $\alpha_{S_{2}-} \mathrm{CN}$ content ( 7 classes); $\beta-\mathrm{CN}_{q}$ is the fixed effect of the $q$ th class of $\beta$-CN content ( 7 classes); $\kappa-\mathrm{CN}_{r}$ is the fixed effect of the $r$ th class of $\kappa-\mathrm{CN}$ content ( 7 classes); $\alpha-\mathrm{LA}_{s}$ is the fixed effect of the sth class of $\alpha$-LA content ( 7 classes); $\beta-\mathrm{LG}_{t}$ is the fixed effect of the th class of $\beta$-LG content ( 7 classes); pendulum ${ }_{u}$ is the fixed effect of the $u$ th pendulum in 2 lactodynamographs (15 pendula); and $\mathrm{e}_{\text {fghijklmnopqrstuv }}$ is the residual random error $\sim N\left(0, \sigma_{e}^{2}\right)$. In the M-\%cas model, $\mathrm{dMY}_{j}$ was substituted by casein ${ }_{j}$ (i.e., the fixed effect of the $j$ th class of casein content in milk; 7 classes), and the protein fractions were expressed as percentage of the total casein content.

The intervals of each of the 7 classes of the protein fractions, dMY, and casein content were half a standard deviation of the trait distribution, with the central class centered at the average of the trait.

Polynomial contrasts $(P<0.05)$ were estimated to examine the response curve of the data regarding the effects of the protein fractions; the first-, second-, and third-order comparisons measured linear, quadratic, and cubic relationships, respectively.

\section{RESULTS}

\section{Descriptive Statistics}

Descriptive statistics of the milk production, nutrient composition (fat, protein, casein, lactose, and SCS), protein fraction, and coagulation traits are shown in
Table 1 . The mean daily yield was $24.4 \mathrm{~kg} / \mathrm{d}$, with a coefficient of variation of $32 \%$. The variability of milk fat, protein, and lactose was much lower $(17,12$, and $4 \%$, respectively), whereas that of SCS was much greater (coefficient of variation $=62 \%)$. The casein concentration in milk was $2.89 \%$ ( $~ 78 \%$ of total protein) and, as expected, was represented mainly by $\beta-\mathrm{CN}$ and $\alpha_{\mathrm{S} 1}-\mathrm{CN}$, with much smaller amounts of $\alpha_{\mathrm{S}_{2}} \mathrm{CN}$ and $\kappa-\mathrm{CN}$ and a very low amount of the 9-phosphorylated form of $\alpha_{\mathrm{S1}^{-}}$ CN. Expressed as proportions of all caseins, the average contents of these proteins were 41.2, 33.0, 11.8, 12.2, and $1.9 \%$, respectively. The mean concentrations of the whey proteins $\beta$-LG and $\alpha$-LA in milk were 3.3 and 0.9 $\mathrm{g} / \mathrm{L}$, respectively, and 11.2 and $3.0 \%$ of the total casein content.

Regarding the single-point MCP traditionally obtained from the lactodynamographic test, average RCT (19.9 $\mathrm{min}$ ) was high due to the inclusion of the values of late-coagulating milk samples ( $\mathrm{RCT}>30 \mathrm{~min}$ ) obtained as a result of prolonging the lactodynamographic test time to $60 \mathrm{~min}$. All the milk samples coagulated within the duration of the lactodynamographic test and only $5.3 \%$ after $30 \mathrm{~min}$ in which $\mathrm{a}_{30}$ was recorded $\left(\mathrm{a}_{30}=0.0\right.$ $\mathrm{mm}$ ). Prolonging time of this analysis permitted us to record the lactodynamographic curves of all samples (including those coagulating after $30 \mathrm{~min}$ from rennet addition) and allowed us to obtain an estimation of the syneresis phase. Regarding the $\mathrm{CF}_{\mathrm{t}}$ equation parameters, $\mathrm{RCT}_{\text {eq }}$ estimated by the model was on average slightly longer than the punctual RCT (20.8 vs. 19.9 min, respectively). The average $\mathrm{CF}_{\mathrm{P}}$ theoretically attainable by the curd was $49.9 \mathrm{~mm}$ due to the $\mathrm{k}_{\mathrm{CF}}$ of $13.0 \% / \mathrm{min}$. However, it was actually possible to reach a $\mathrm{CF}_{\max }$ of only $37.2 \mathrm{~mm}$ after an average of $41.7 \mathrm{~min}$ $\left(t_{\max }\right)$ from rennet addition because of the syneresis rate of $1.24 \% / \mathrm{min}$. Almost all the traits analyzed had a distribution close to normal (skewness and kurtosis values $-1.00<\mathrm{x}<1.00$; data not shown), with a few exceptions represented by fat (leptokurtic, 3.59) and $\mathrm{k}_{20}$ and and $\mathrm{t}_{\max }$ (right skewed, 1.34 and 1.44, respectively).

\section{Single-Point MCP}

Table 2 shows the results of the linear mixed models (quantitative model $\mathrm{M}-\mathrm{g} / \mathrm{L}$ and qualitative model M$\%$ cas; $F$-values and significance) for traditional singlepoint MCP with respect to the effects included in the models (dairy system; herd; DIM; parity; pendulum; genotypes of $\beta-\mathrm{CN}, \kappa-\mathrm{CN}$, and $\beta-\mathrm{LG}$; and $\mathrm{dMY}$ ) and the results of the linear, quadratic, and cubic contrasts ( $F$-values and significance) of the effects of total casein and milk protein fractions. The fixed effects of milk protein fractions were included as grams per liter of 
Table 1. Descriptive statistics of single test-day milk yield (dMY), milk composition, protein fractions ( $\mathrm{g} / \mathrm{L}$ in milk and $\%$ of casein), traditional coagulation properties, and curd firming time $\left(\mathrm{CF}_{\mathrm{t}}\right)$ model parameters ${ }^{1}$

\begin{tabular}{|c|c|c|c|c|c|}
\hline Trait $^{2}$ & $\mathrm{n}$ & Mean & $\mathrm{SD}$ & $\mathrm{P} 5$ & P95 \\
\hline $\mathrm{dMY}, \mathrm{kg} / \mathrm{d}$ & 1,246 & 24.4 & 7.9 & 12.3 & 37.9 \\
\hline \multicolumn{6}{|c|}{ Milk composition } \\
\hline Fat, \% & 1,229 & 4.22 & 0.73 & 3.14 & 5.42 \\
\hline Protein, \% & 1,229 & 3.71 & 0.44 & 3.03 & 4.43 \\
\hline Casein, \% & 1,229 & 2.89 & 0.33 & 2.38 & 3.44 \\
\hline Lactose, \% & 1,229 & 4.85 & 0.20 & 4.50 & 5.13 \\
\hline SCS, unit & 1,229 & 2.98 & 1.86 & 0.21 & 6.20 \\
\hline \multicolumn{6}{|c|}{ Protein fractions, $\mathrm{g} / \mathrm{L}$} \\
\hline$\alpha_{\mathrm{S}^{-}} \mathrm{CN}$ & 1,229 & 9.5 & 1.3 & 7.6 & 11.8 \\
\hline$\alpha_{\mathrm{S}^{-}}-\mathrm{CNph}^{2}$ & 1,227 & 0.5 & 0.2 & 0.2 & 1.0 \\
\hline$\alpha_{\mathrm{S}^{-}} \mathrm{CN}$ & 1,229 & 3.4 & 0.6 & 2.5 & 4.4 \\
\hline$\beta-\mathrm{CN}$ & 1,229 & 11.9 & 1.5 & 9.5 & 14.4 \\
\hline$\kappa-\mathrm{CN}$ & 1,229 & 3.5 & 0.7 & 2.3 & 4.6 \\
\hline$\beta-\mathrm{LG}$ & 1,229 & 3.3 & 0.7 & 2.2 & 4.5 \\
\hline$\alpha-\mathrm{LA}$ & 1,229 & 0.9 & 0.2 & 0.6 & 1.2 \\
\hline \multicolumn{6}{|c|}{ Protein fractions, $\%$ of casein } \\
\hline$\alpha_{\mathrm{S} 1}-\mathrm{CN}$ & 1,224 & 33.0 & 2.1 & 29.6 & 36.7 \\
\hline$\alpha_{\mathrm{S} 1}-\mathrm{CNph}$ & 1,227 & 1.9 & 0.8 & 0.6 & 3.3 \\
\hline$\alpha_{\mathrm{S}_{2}}-\mathrm{CN}$ & 1,226 & 11.8 & 1.5 & 9.7 & 14.4 \\
\hline$\beta-\mathrm{CN}$ & 1,229 & 41.2 & 3.0 & 37.0 & 46.7 \\
\hline$\kappa-\mathrm{CN}$ & 1,217 & 12.2 & 1.8 & 8.8 & 14.6 \\
\hline$\beta-\mathrm{LG}$ & 1,228 & 11.2 & 2.0 & 8.2 & 14.5 \\
\hline$\alpha-L A$ & 1,229 & 3.0 & 0.7 & 1.9 & 4.1 \\
\hline \multicolumn{6}{|c|}{ Coagulation properties } \\
\hline $\mathrm{RCT}, \min$ & 1,247 & 19.9 & 5.7 & 12.3 & 31.3 \\
\hline $\mathrm{k}_{20}, \min$ & 1,207 & 5.3 & 2.3 & 2.5 & 10.3 \\
\hline $\mathrm{a}_{30}, \mathrm{~mm}$ & 1,253 & 28.0 & 12.6 & 0.0 & 44.9 \\
\hline \multirow{2}{*}{\multicolumn{6}{|c|}{$\mathrm{CF}_{\mathrm{t}}$ parameters }} \\
\hline & & & & & \\
\hline $\mathrm{RCT}_{\mathrm{eq}}, \min$ & 1,246 & 20.8 & 5.8 & 13.0 & 32.3 \\
\hline $\mathrm{CF}_{\mathrm{P}}, \mathrm{mm}$ & 1,253 & 49.9 & 9.8 & 34.3 & 66.4 \\
\hline $\mathrm{k}_{\mathrm{CF}}, \% / \min$ & 1,253 & 13.0 & 4.1 & 6.3 & 19.8 \\
\hline $\mathrm{k}_{\mathrm{SR}}, \% / \min$ & 1,253 & 1.2 & 0.5 & 0.5 & 2.0 \\
\hline $\mathrm{CF}_{\max }, \mathrm{mm}$ & 1,253 & 37.2 & 7.3 & 25.6 & 49.5 \\
\hline $\mathrm{t}_{\max }, \min$ & 1,253 & 41.7 & 12.4 & 26.5 & 67.3 \\
\hline
\end{tabular}

${ }^{1} \mathrm{P} 5=5$ th percentile; P95 $=95$ th percentile.

${ }^{2} \alpha_{\mathrm{S1}_{1}} \mathrm{CNph}=\alpha_{\mathrm{S1}} \mathrm{CN}$ with 1 more phosphorylated serine residue; $\mathrm{RCT}=$ rennet coagulation time; $\mathrm{RCT}_{\mathrm{eq}}=$ estimated RCT; $\mathrm{k}_{20}=$ time from coagulation to a curd firmness of $20 \mathrm{~mm}$; $\mathrm{a}_{30}=$ curd firmness $30 \mathrm{~min}$ after rennet addition; $\mathrm{a}_{45}=$ curd firmness $45 \mathrm{~min}$ after rennet addition; $\mathrm{CF}_{\mathrm{P}}=$ asymptotical potential value of curd firmness; $\mathrm{k}_{\mathrm{CF}}=$ curd-firming instant rate constant; $\mathrm{k}_{\mathrm{SR}}=$ syneresis instant rate constant; $\mathrm{CF}_{\max }=\operatorname{maximum}$ curd firmness achieved within $90 \mathrm{~min} ; \mathrm{t}_{\max }=$ time at achievement of $\mathrm{CF}_{\max }$.

milk together with dMY (model M-g/L) or were included as proportions of total casein together with the casein content of milk (model M-\%cas).

The effects of CSN2, CSN3, and BLG genotypes were included in the models to analyze the effect of the protein fraction content on MCP after removing any influence of these 3 genes that might give biased estimations. In fact, all 3 genotypes exhibited some effects on MCP that were not mediated by the milk protein fraction content.

Milk production, included in the $\mathrm{M}-\mathrm{g} / \mathrm{L}$ model, marginally affected $\mathrm{a}_{45}$, whereas the casein content, included in the M-\%cas model, strongly affected all MCP (almost linearly) except RCT. In fact, the $\mathrm{k}_{20}$ was highly reduced (from 7.43 to $4.66 \mathrm{~min}$ ) by the increase in the casein content, whereas the curd firmness was significantly improved (from 22.8 to $30.5 \mathrm{~mm}$ for $\mathrm{a}_{30}$ and from 23.4 to $36.9 \mathrm{~mm}$ for $\mathrm{a}_{45}$ ). It should be noted that $\alpha_{\mathrm{S} 1}-\mathrm{CNph}$ did not affect any MCP and that $\alpha-\mathrm{LA}$ exerted only a minor effect on $\mathrm{a}_{45}$ (Figure 1).

The RCT was linearly increased by the content of $\alpha_{\mathrm{S}_{2}} \mathrm{CN}$ and $\beta$-LG in milk (unfavorable effect on the coagulation process) and decreased by the content of $\alpha_{\mathrm{S} 1}-\mathrm{CN}$ and $\kappa-\mathrm{CN}$ (favorable effect on the coagulation process). When expressed as a proportion of the total casein content (M-\%cas), only the unfavorable effects of $\alpha_{\mathrm{S}_{2}} \mathrm{CN}$ and $\beta-\mathrm{LG}$ were confirmed, whereas $\alpha_{\mathrm{S} 1}-\mathrm{CN}$ and $\kappa-\mathrm{CN}$ had a null or slight effect on RCT.

After gelation, the curd begins the firming phase. The time required to reach $\mathrm{k}_{20}$, considered suitable for curd cutting, was shortened by the $\alpha_{\mathrm{S1}^{-}} \mathrm{CN}$ and $\kappa-\mathrm{CN}$ content in milk and to a lesser degree by the $\beta$-CN content, whereas the $\beta$-LG content was associated with a delay in $k_{20}$. When expressed as a proportion of the 
Table 2. Results from linear mixed models ( $F$-value and significance) for traditional single-point milk coagulation properties ${ }^{1}$

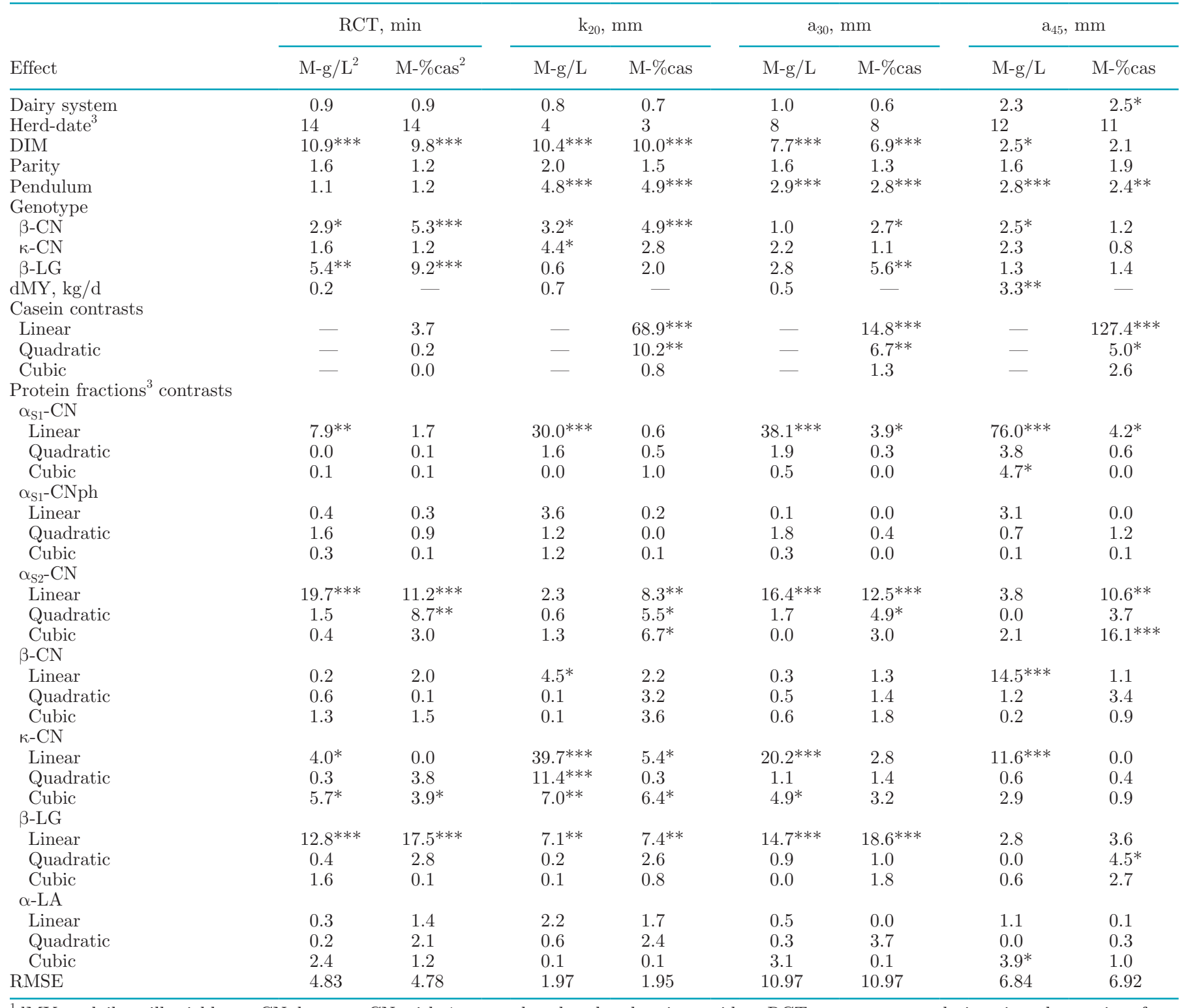

${ }^{1} \mathrm{dMY}=$ daily milk yield; $\alpha_{\mathrm{S}^{-}} \mathrm{CNph}=\alpha_{\mathrm{S1}^{-}} \mathrm{CN}$ with 1 more phosphorylated serine residue; $\mathrm{RCT}=$ rennet coagulation time; $\mathrm{k}_{20}=$ time from coagulation to reach $20 \mathrm{~mm}$ of curd firmness; $\mathrm{a}_{30}=$ curd firmness at $30 \mathrm{~min}$ of analysis; $\mathrm{a}_{45}=$ curd firmness at 45 min of analysis; RMSE $=$ root mean squared error.

${ }^{2} \mathrm{M}-\mathrm{g} / \mathrm{L}=$ quantitative model included the protein fractions expressed in grams per liter of milk; M-\%cas = qualitative model included the protein fractions expressed as proportion of total casein.

${ }^{3}$ Herd-date effect expressed as proportion of variance explained by herd/test date calculated by dividing the corresponding variance component by the total variance.

${ }^{*} P<0.05 ;{ }^{* *} P<0.01 ;{ }^{* * *} P<0.001$.

casein content, only $\kappa$-CN showed a favorable effect on $\mathrm{k}_{20}$ (reduced from 7.54 to $4.45 \mathrm{~min}$ ), whereas $\alpha_{\mathrm{S}_{2}} \mathrm{CN}$ and $\beta$-LG exerted an unfavorable effect (increased from 5.38 to $6.02 \mathrm{~min}$ by the $\alpha_{\mathrm{S}_{2}} \mathrm{CN}$ and from 5.21 to 6.05 min by the $\beta-\mathrm{LG}$ ).

In the case of single-point curd firmness traits $\left(\mathrm{a}_{30}\right.$ and $\mathrm{a}_{45}$ ), we found that the increase in $\alpha_{\mathrm{S}_{1}} \mathrm{CN}$ and $\kappa-\mathrm{CN}$ had a positive effect (both the traits increased from about $20 \mathrm{~mm}$ to over $30 \mathrm{~mm})$. On the contrary, the increase in $\alpha_{\mathrm{S}_{2}}$-CN and $\beta$-LG had a negative effect (both the curd firmness traits decreased under $30 \mathrm{~mm}$ ). These effects showed whether the protein fractions were expressed quantitatively ( $\mathrm{g} / \mathrm{L}$ in milk) or qualitatively (\% of total casein). In addition, $\beta-\mathrm{CN}$ had a favorable effect on $\mathrm{a}_{45}$ (from 27.4 to $33.3 \mathrm{~mm}$ ), but only when expressed as total content in milk $(\mathrm{g} / \mathrm{L})$. 


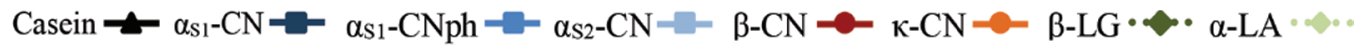
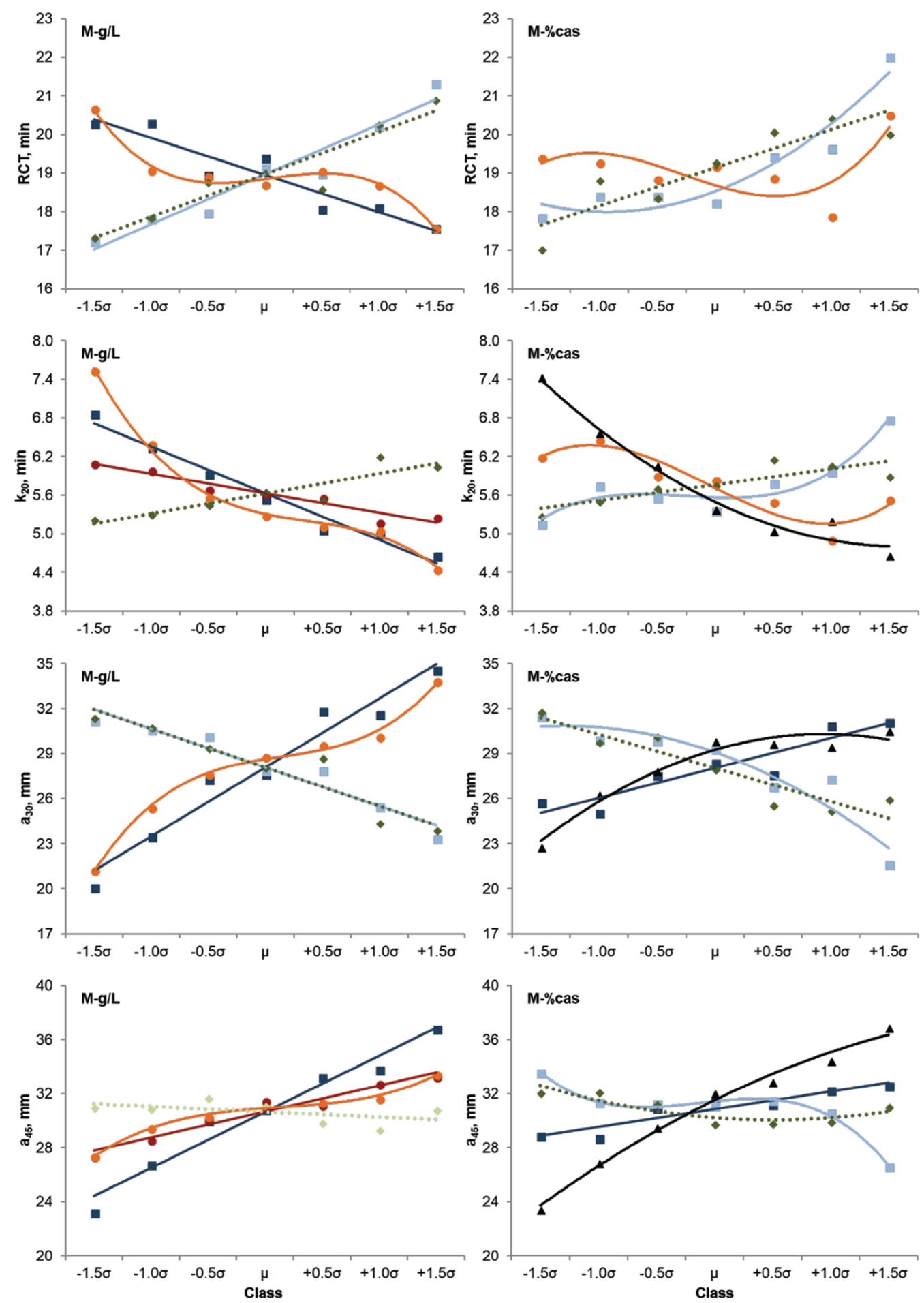

Figure 1. Effect of milk protein fractions content on traditional milk coagulation properties: $\mathrm{RCT}=$ rennet coagulation time; $\mathrm{k}_{20}=$ the time from coagulation to a curd firmness of $20 \mathrm{~mm} ; \mathrm{a}_{30}=$ curd firmness $30 \mathrm{~min}$ after rennet addition; $\mathrm{a}_{45}=$ curd firmness 45 min after rennet addition. $\alpha_{\mathrm{S1}} \mathrm{CNph}=\alpha_{\mathrm{S1}}-\mathrm{CN}$ with 1 more phosphorylated serine residue. Solid and dotted lines represent the results of the polynomial contrasts (linear, quadratic, or cubic) as the trend of the traits in response to the quantitative (protein fractions expressed as grams per liter of milk; $\mathrm{M}$ - $\mathrm{g} / \mathrm{L}$ ) and qualitative (protein fractions expressed as percentage of the total casein content; M-\%cas) effect of milk protein fractions: solid lines represent casein fractions effect and dotted lines represent whey protein fractions effect. Only the significant polynomial contrasts are represented. For each protein fraction, the classes were constituted by half standard deviation $(0.5 \sigma)$ of the protein fraction distribution, with the central class centering the average of the protein fraction. 
Table 3. Results from linear mixed models ( $F$-value and significance) for curd firming time $\left(\mathrm{CF}_{\mathrm{t}}\right)$ equation parameters ${ }^{1}$

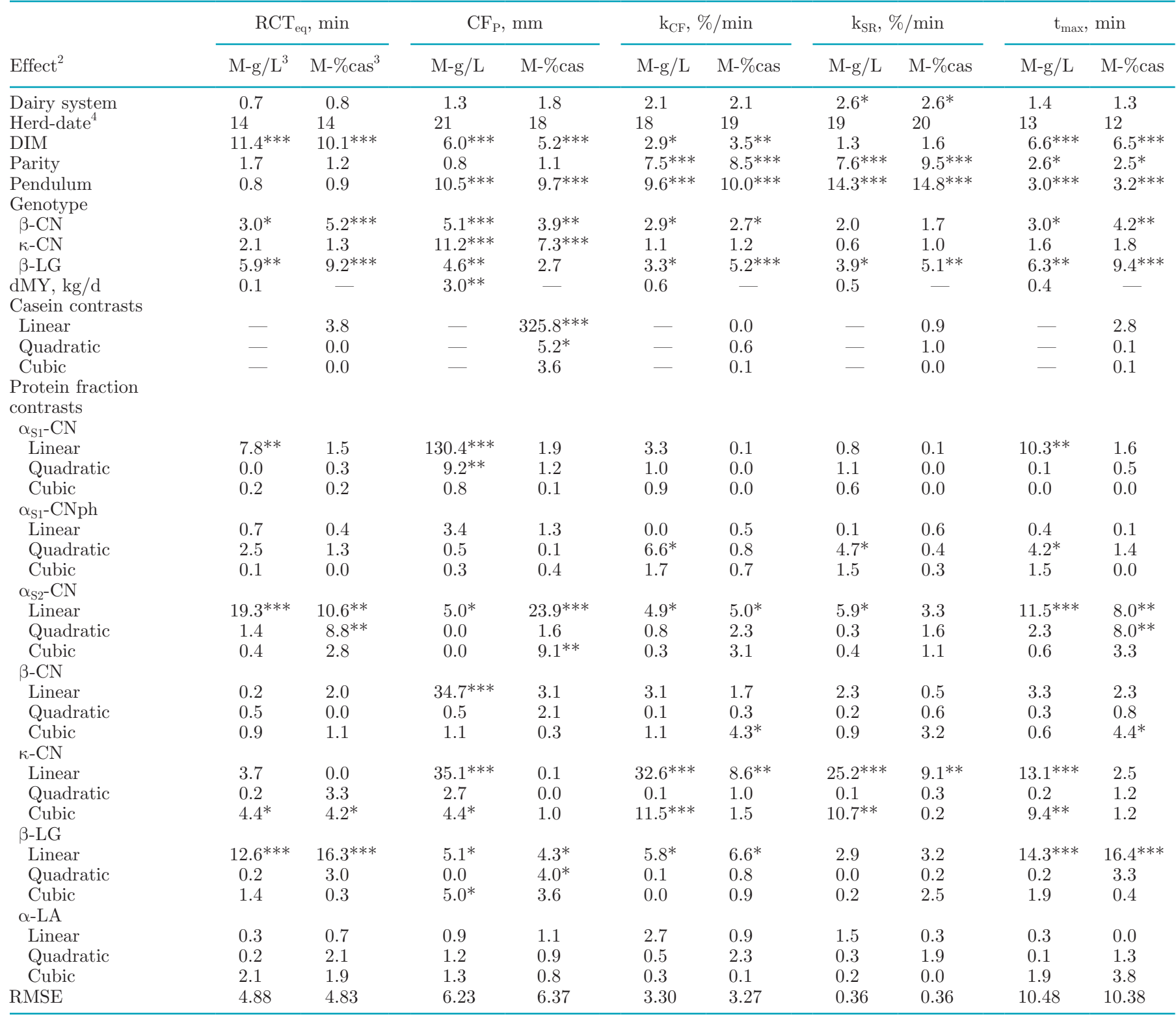

${ }^{1} \mathrm{RCT}_{\mathrm{eq}}=$ estimated rennet coagulation time; $\mathrm{CF}_{\mathrm{P}}=$ asymptotical potential value of curd firmness; $\mathrm{k}_{\mathrm{CF}}=$ curd-firming instant rate constant; $\mathrm{k}_{\mathrm{SR}}=$ syneresis instant rate constant; $\mathrm{t}_{\max }=$ time at achievement of $\mathrm{CF}_{\max }$.

${ }^{2} \mathrm{dMY}=$ daily milk yield; $\alpha_{\mathrm{S} 1} \mathrm{CNph}=\alpha_{\mathrm{S1}} \mathrm{CN}$ with 1 more phosphorylated serine residue; RMSE = root mean squared error.

${ }^{3} \mathrm{M}-\mathrm{g} / \mathrm{L}=$ quantitative model included the protein fractions expressed in grams per liter of milk; M-\%cas = qualitative model included the protein fractions expressed as proportion of total casein.

${ }^{4}$ Herd-date effect expressed as proportion of variance explained by herd/test date calculated by dividing the corresponding variance component by the total variance.

${ }^{*} P<0.05 ;{ }^{* *} P<0.01 ;{ }^{* * *} P<0.001$.

\section{$\mathrm{CF}_{t}$ Equation Parameters}

Table 3 shows the results of the linear mixed model (model M-g/L and model M-\%cas; $F$-values and significance) for the curd firming $\left(\mathrm{CF}_{\mathrm{t}}\right)$ equation parameters and the results of the linear, quadratic, and cubic contrasts ( $F$-values and significance) for the milk protein fractions, and Figure 2 shows the least squares means of the effects of the milk protein fractions.

Daily milk yield, included in the $\mathrm{M}-\mathrm{g} / \mathrm{L}$ model, showed a modest positive effect on $\mathrm{CF}_{\mathrm{P}}$ (from 43.8 to $47.8 \mathrm{~mm}$ ), whereas casein content, included in the M\%cas model, showed a strong, favorable, almost linear effect on the same trait (from 36.3 to $56.2 \mathrm{~mm}$ ). The 


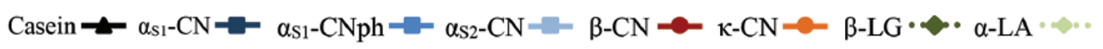
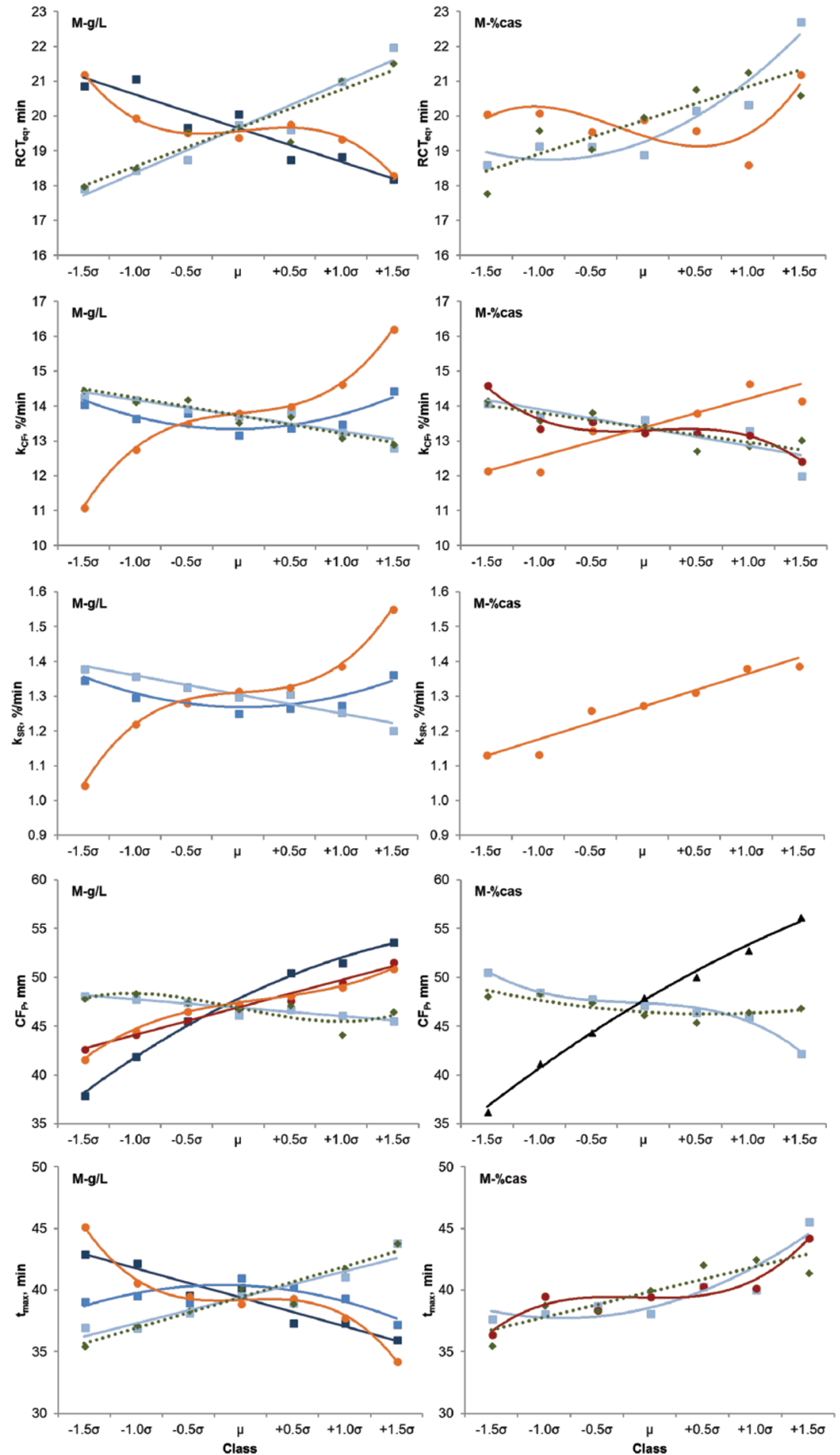

Figure 2. Effect of milk protein fractions content on curd firmness over time $\left(\mathrm{CF}_{\mathrm{t}}\right)$ equation parameters: $\mathrm{RCT}_{\mathrm{eq}}=$ estimated rennet coagulation time; $\mathrm{CF}_{\mathrm{P}}=$ asymptotical potential value of curd firmness; $\mathrm{k}_{\mathrm{CF}}=$ curd-firming instant rate constant; $\mathrm{k}_{\mathrm{SR}}=$ syneresis instant rate constant; $t_{\max }=$ time at achievement of the maximu CF value. Solid and dotted lines represent the results of the polynomial contrasts (linear, quadratic, or cubic) as the trend of the traits in response to the quantitative (protein fractions expressed as grams per liter of milk; M-g/L) and qualitative (protein fractions expressed as percentage of the total casein content; M-\%cas) effect of milk protein fractions: solid lines represent casein fractions effect and dotted lines represent whey protein fractions effect. Only the significant polynomial contrasts are represented. For each protein fraction, the classes were constituted by half standard deviation $(0.5 \sigma)$ of the protein fraction distribution, with the central class centering the average of the protein fraction. 

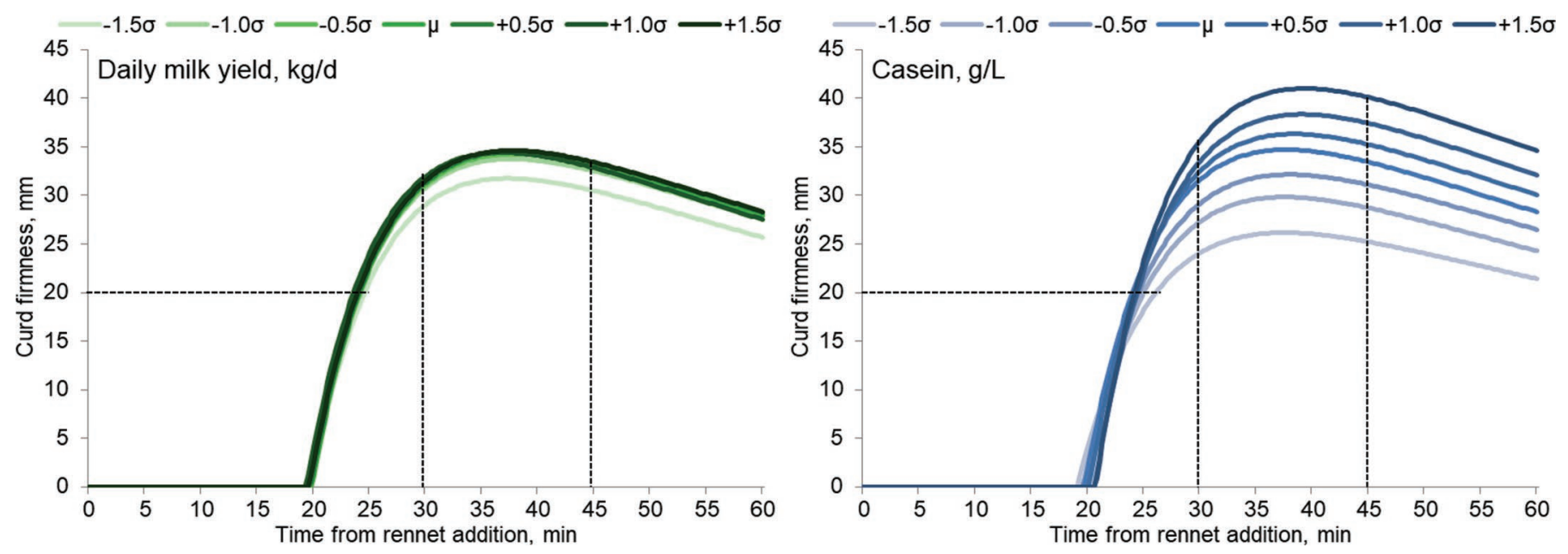

Figure 3. Pattern of curd firmness after rennet addition $\left(\mathrm{CF}_{\mathrm{t}}\right.$ modeling) of milk samples according to daily milk production (kg/d) and casein content $(\mathrm{g} / \mathrm{L})$. The intersection of the horizontal black dashed line and of the vertical black dashed line at 30 and 45 min with firmness curves represents $\mathrm{k}_{20}$ (the time from coagulation to a curd firmness of $20 \mathrm{~mm}$ ), $\mathrm{a}_{30}$ (curd firmness 30 min after rennet addition), and $\mathrm{a}_{45}$ (curd firmness 45 min after rennet addition) of milk samples, respectively. For daily milk production and casein content, the classes were constituted by half $\mathrm{SD}(0.5 \sigma)$ of the trait distribution, with the central class centering the average of the trait.

tendency for favorable effects of $\alpha_{\mathrm{S} 1}-\mathrm{CN}$ (in $\mathrm{g} / \mathrm{L}$ on $\mathrm{RCT}_{\text {eq }}, \mathrm{CF}_{\mathrm{P}}$, and $\mathrm{t}_{\max }$ ), $\beta-\mathrm{CN}$ (in $\mathrm{g} / \mathrm{L}$ on $\mathrm{CF}_{\mathrm{P}}$ ), and $\kappa-\mathrm{CN}$ (on $\mathrm{CF}_{\mathrm{P}}, \mathrm{k}_{\mathrm{CF}}, \mathrm{k}_{\mathrm{SR}}$, and $\mathrm{t}_{\max }$ ) and for unfavorable effects of $\alpha_{\mathrm{S}^{2}} \mathrm{CN}$ and $\beta$-LG (on all these traits) were also confirmed by the $\mathrm{CF}_{\mathrm{t}}$ equation parameters, as were the negligible effects of $\alpha_{\mathrm{S} 1}-\mathrm{CNph}$ and $\alpha-\mathrm{LA}$.

\section{DISCUSSION}

\section{Effects of Milk Yield and Casein Content on Milk Coagulation, Curd Firming, and Syneresis}

The adoption of $\mathrm{CF}_{\mathrm{t}}$ modeling allowed the effects of a given factor on different equation parameters to be combined in graphic form and the resulting pattern of $\mathrm{CF}_{\mathrm{t}}$ to be drawn. This approach allowed us to capture the relative importance of the different factors tested on the technological properties of milk. Figure 3 shows the $\mathrm{CF}_{\mathrm{t}}$ modeling curves represented in function of daily milk yield ( $\mathrm{dMY}, \mathrm{kg} / \mathrm{d})$ and the casein content of milk $(\mathrm{g} / \mathrm{L})$. Neither of the 2 factors greatly affected the time interval between rennet addition and milk gelation $\left(\mathrm{RCT}_{\text {eq }}\right)$. Daily milk yield also had a negligible effect on the curd firming process, except for the very low milk production class, which exhibited lower curd firmness than other classes in the extended period (after $30 \mathrm{~min}$ ). In contrast, total casein content strongly affected the pattern of curd firming over time and generated a family of curves characterizing the 7 classes of casein content in milk $(\mathrm{g} / \mathrm{L})$, which differed almost only in $\mathrm{CF}_{\max }$ as a consequence of the increase in asymptotical curd firmness $\left(\mathrm{CF}_{\mathrm{P}}\right)$, although not in the 2 instant rate constants of curd firming $\left(\mathrm{k}_{\mathrm{CF}}\right)$ and syneresis $\left(k_{\mathrm{SR}}\right)$, which characterized the increasing and decreasing phases of the curves, respectively.

These patterns fully confirmed the results of the correlations between these 2 traits and traditionally reported MCP $\left(\mathrm{RCT}, \mathrm{k}_{20}, \mathrm{a}_{30}, \mathrm{a}_{45}\right)$. In fact, in the various studies reviewed by Bittante et al. (2012), dMY presented very low phenotypic and genetic correlations with RCT (on average small and positive) and with $\mathrm{a}_{30}$ (small and negative), whereas milk casein content exhibited almost null correlations with RCT and always positive correlations with $\mathrm{a}_{30}$ (on average, phenotypic $+0.32 \pm 0.18$, genetic $+0.42 \pm 0.23)$. Ikonen et al. (2004) showed that $\mathrm{pH}$ is the principal factor affecting coagulation time.

It is worth noting that in the present study the quantity of rennet added to the milk was relatively small and similar to that used for producing PDO cheeses (Stocco et al., 2015) but much smaller than the amount used in some other studies (Ikonen et al., 1999; Tyrisevä et al., 2004; Vallas et al., 2010). Moreover, the same quantity of rennet was added to all the samples regardless of the casein concentration of the milk. Thus, the ratio between rennet and casein decreased as the casein content increased. It is clear, however, that rennet was never limiting the coagulation. In fact, if a fixed ratio between rennet and casein had been adopted, it would perhaps have induced an even stronger positive effect of casein concentration on the coagulation, curd firming, and syneresis processes.

In light of the marked effect of the increasing casein content in milk $(\mathrm{g} / \mathrm{L})$ on the $\mathrm{CF}_{\mathrm{t}}$ pattern, we may also expect the individual casein fractions, when expressed in grams per liter of milk, to have an influence on the 
coagulation. In fact, it appears from the curves depicted in Figure 4 that all the casein fractions, with the exception of $\alpha_{S_{1}} \mathrm{CNph}$ (not included in the figure), strongly affected the $\mathrm{CF}_{\mathrm{t}}$ pattern, but each in a different way.

\section{Effects of $\alpha_{s_{1}}-\mathrm{CN}$ on Milk Coagulation, Curd Firming, and Syneresis}

One of the 2 major casein fractions in bovine milk is $\alpha_{\mathrm{S}^{-}} \mathrm{CN}$, and among all the casein fractions, it was the one that exhibited the greatest effect on the $\mathrm{CF}_{t}$ curve (Figure 4), which was very similar in shape and only on a lower scale than the total casein content in milk (Figure 3). In fact, both the total casein and the $\alpha_{\mathrm{S1}}$-CN increased the $\mathrm{CF}_{\max }$ and had no effect on the syneresis phase (the curves were parallel in the decreasing phase). The similarity between the effect of the quantity of this casein in milk and the effect of total casein content is confirmed by the results obtained with the statistical model M-\%cas. The model showed that when the total quantity of casein was fixed, the variation in the proportion of $\alpha_{\mathrm{S}_{1}}$ CN of total casein content (qualitative effect) was not very high (Figure 4).

This result is in agreement with Jõudu et al. (2008) even though the genetic, environmental, and analytical conditions were very different from those in this study. In fact, they found a high correlation between $\alpha_{\mathrm{S} 1}$-CN content in milk and curd firmness $(+0.638)$, whereas the correlation was almost negligible $(+0.101)$ when this casein fraction was expressed as a percentage of total casein content. In contrast to these results, Bonfatti et al. (2010) found a favorable effect of $\alpha_{S_{1}-} \mathrm{CN}$ on curd firmness in Simmental cows only when it was expressed as a proportion of total caseins. Considering that $\alpha_{\mathrm{S} 1} \mathrm{CN}$, along with $\beta$-CN, is the most abundant protein fraction in milk, it may be that the increase in this fraction makes more raw matter available for the coagulum and for the formation of a more consistent curd that could help retention of the other milk nutrients. In this situation, it could be possible to obtain higher curd firmness values at the same rate of curd firming and syneresis. Other authors have also found that the $\alpha_{\mathrm{S}_{1}} \mathrm{CN}$ fraction in milk has a favorable effect on curd firmness (Marziali and Ng-Kwai-Hang, 1986; Politis and Ng-Kwai-Hang, 1988).

\section{Effects of $\alpha_{S^{2}}-C N$ on Milk Coagulation, Curd Firming, and Syneresis}

It is clear from Figure 4 that $\alpha_{\mathrm{S}^{-}} \mathrm{CN}(\mathrm{g} / \mathrm{L})$ has almost the opposite effect as $\alpha_{\mathrm{S1}^{-}} \mathrm{CN}$, for which it delays milk gelation and reduces the $\mathrm{CF}_{\max }$ and syneresis (see the slope of the curve after $\mathrm{CF}_{\max }$ ). When expressed as a proportion of total casein, the negative effect of its increase is accentuated because its own negative effect is added to the parallel reduction of the other (favorable) casein fractions, such as $\mathrm{k}$-CN. This effect is not linearly proportional to the incidence of $\alpha_{S_{2}}-\mathrm{CN}$ on total casein because it is particularly evident for the highest proportion class (Figure 4).

This pattern differs partially from that reported by Jõudu et al. (2008), who found that $\alpha_{\mathrm{S}^{2}} \mathrm{CN}$ had a slightly favorable effect on coagulation time and on curd firmness when expressed as grams per liter of milk but an unfavorable effect, as in this study, when expressed as a proportion of total casein. They also found the poorly or noncoagulated milk samples to have higher concentrations of $\alpha_{S_{2}}-\mathrm{CN}$ out of total casein, especially at the expense of the $\kappa-\mathrm{CN}$ concentrations. Bonfatti et al. (2010) also observed an unfavorable effect of $\alpha_{S_{2}} \mathrm{CN}$ in grams per liter on RCT but a favorable effect on $\mathrm{a}_{30}$ when expressed as a proportion of total caseins.

\section{Effects of $\beta-C N$ on Milk Coagulation, Curd Firming, and Syneresis}

The $\beta$-CN fraction is the most abundant protein fraction in bovine milk (Table 1 ). The effect of its amount in milk $(\mathrm{g} / \mathrm{L})$ on coagulation, curd firming, and syneresis is similar to that of $\alpha_{S 1}-\mathrm{CN}$ and total casein. In fact, like $\alpha_{\mathrm{S} 1}-\mathrm{CN}$ and total casein, it has a negligible effect on coagulation time and syneresis and a favorable effect on $\mathrm{CF}_{\max }$ (reaching higher values). The main difference is that the degree of the $\beta$-CN effect on $\mathrm{CF}_{\max }$ is almost half that of $\alpha_{\mathrm{S}_{1}} \mathrm{CN}$. This explains the fact that, when expressed as a proportion of total casein, an increase in $\beta$-CN corresponds to a decrease in the other caseins and its effect becomes unfavorable (unfavorable substitution effect).

Jõudu et al. (2008) also found that an increase in $\beta-\mathrm{CN}$ in milk was favorably correlated with RCT and $\mathrm{a}_{30}$, but the correlation was almost null with RCT and unfavorable with $\mathrm{a}_{30}$ when $\beta-\mathrm{CN}$ was expressed as a proportion of total casein. Only Bonfatti et al. (2010), in a study on Simmental cows, found a positive effect of this casein fraction on $\mathrm{a}_{30}$ when expressed as grams per liter or as percentage of total casein content.

The negative effect was indirectly confirmed by StGelais and Haché (2005), who found poor coagulation in milk samples enriched with $\beta-\mathrm{CN}$ and, in agreement with Dunnewind et al. (1996) and De Roos et al. (2000), reported a reduction in the affinity between $\kappa-\mathrm{CN}$ and chymosin after the addition of $\beta-\mathrm{CN}$. According to these studies, this fraction seems to act as a competitor with the proteolytic enzyme or as a shield for the enzyme binding sites during coagulation. From another point of view, the content of this fraction is also associated with the formation of casein micelles with a large diameter 

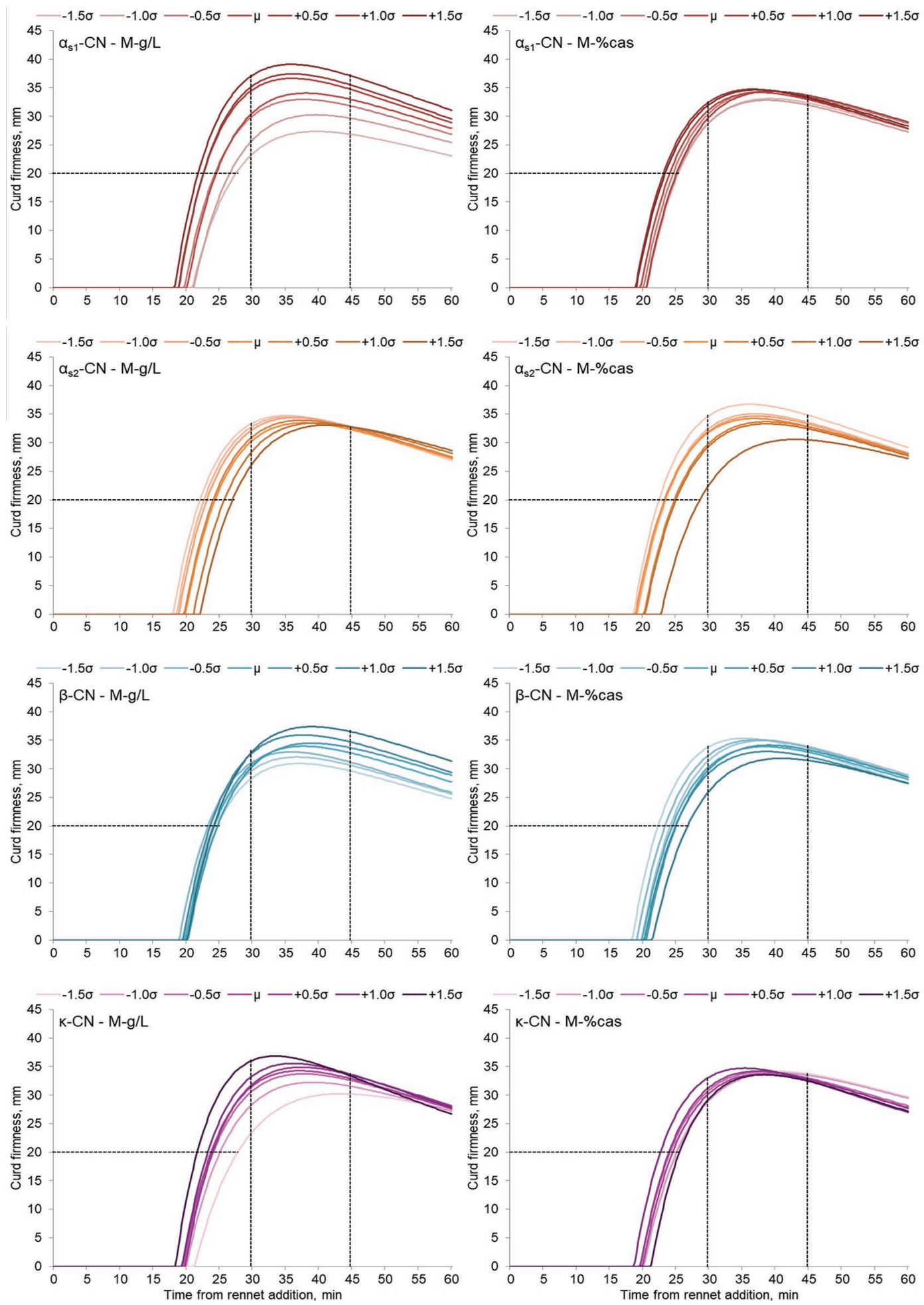

Figure 4. Pattern of curd firmness after rennet addition $\left(\mathrm{CF}_{\mathrm{t}}\right.$ modeling) of milk samples according to milk casein fractions $\left(\alpha_{\mathrm{S1}^{-}} \mathrm{CN}, \alpha_{\mathrm{S2} 2} \mathrm{CN}\right.$, $\beta-\mathrm{CN}$, and $\kappa-\mathrm{CN}$ ) content. For each fraction, results from the quantitative model (protein fractions expressed as grams per liter of milk; M-g/L) and from the qualitative model (protein fractions expressed as percentage of the total casein content; M-\%cas) are presented. The intersection of the horizontal black dashed line and of the vertical black dashed line at 30 and 45 min with firmness curves represents $\mathrm{k}_{20}$ (the time from coagulation to a curd firmness of $20 \mathrm{~mm}$ ), $\mathrm{a}_{30}$ (curd firmness 30 min after rennet addition), and $\mathrm{a}_{45}$ (curd firmness 45 min after rennet addition) of milk samples, respectively. For each casein fraction, the classes were constituted by half SD $(0.5 \sigma)$ of the casein fraction distribution, with the central class centering the average of the casein fraction. 
(Dalgleish, 1993). These large micelles create too wide a casein net during coagulation and the release of more nutrients into the whey. It seems possible that the presence of these large micelles in large quantities, together with a low $\kappa$-CN content, could reduce the enzymatic action of rennet during coagulation and the retention of nutrients in the curd.

\section{Effects of $\mathrm{k}-\mathrm{CN}$ on Milk Coagulation, Curd Firming, and Syneresis}

The $\kappa$-CN fraction also had a strong effect on the entire coagulation, curd firming, and syneresis process. This effect is more evident when this fraction is expressed as content in milk (Figure 4). In fact, the increase in this casein fraction had a small favorable effect on coagulation time and a large favorable effect on the other equation parameters $\left(\mathrm{CF}_{\mathrm{P}}, \mathrm{k}_{\mathrm{CF}}\right.$, and $\left.\mathrm{k}_{\mathrm{SR}}\right)$ and consequently on the derived traits $\mathrm{CF}_{\max }$ and $\mathrm{t}_{\max }$, as is clearly shown by the slopes of the ascending and decreasing phases of the curve as well as by the maximum values reached and the time needed to reach them. It worth noting that, differently from some other studies, these effects of $\kappa$-CN content have been quantified disaggregating the contemporary effect of its genetic variants.

These results are consistent with those of many authors who have found lower contents and proportions of $\kappa-\mathrm{CN}$ in noncoagulated and poorly coagulated samples and higher contents and proportions in well-coagulated milk (Wedholm et al., 2006; Jõudu et al., 2008). The explanation given for this effect is the negative correlation between the content of this casein fraction and the diameter of the casein micelles. The presence of small micelles can increase the number of bonds between the micelles per surface unit, leading to the formation of a tighter casein net, which is more able to entrap the other milk nutrients. In this way it improves curd firmness and favors whey expulsion by increasing curd syneresis. Moreover, a higher content of $\kappa-\mathrm{CN}$ could make the milk more reactive to the rennet and hence reduces the critical level of clotting onset, which may explain the rapid onset of coagulation (Bonfatti et al., 2010).

\section{Effects of Whey Proteins on Milk Coagulation, Curd Firming, and Syneresis}

It can be seen in Figure 5 that the greater amount of $\beta$-LG in milk had a detrimental effect on coagulation, prolonging RCT and reducing curd firmness. The same pattern was found when this whey protein is expressed as a ratio to total casein content. This is not expected because in this case there is no effect of substituting whey proteins with caseins. In fact, an effect of substi- tution would be present if whey proteins were expressed as a proportion of total milk proteins.

Various studies that expressed this whey protein as a percentage of total milk protein found the $\beta-\mathrm{LG}$ content to be associated with poor coagulation properties (Jensen et al., 2012a; Ketto et al., 2017). Some of the authors assumed this effect to be due to an increase in the whey protein content at the expense of the casein fractions, which can lead to a reduction in raw matter for coagulation, but this does not seem to be confirmed by our study. In contrast, Jõudu et al. (2008) found that an increase in the content of $\beta$-LG in milk improved coagulation time and curd firmness. It is worth noting that some of the discrepancies of other work with our results could be due to the fact that the majority of these studies did not analyze or include the genetic variants of $\beta$-LG in the statistical model. In fact, several authors did indeed find a strong effect of $\beta-L G$ genetic variants on milk coagulation and curd firmness (Marziali and Ng-Kwai-Hang, 1986; Heck et al., 2009; Poulsen et al., 2017).

The high content of $\alpha$-LA is generally associated with poorly coagulated and noncoagulated milks, which is often explained in terms of a positive correlation between $\alpha$-LA and $\beta$-LG contents (Jensen et al., 2012b; Ketto et al., 2017; Poulsen et al., 2017). In the present work, no clear effect seems to be triggered by an increase in the amounts or proportions of this whey protein (Figure 5).

\section{CONCLUSIONS}

We demonstrated in this study that almost all of the protein fractions have an important and specific role in the different phases of the coagulation process. We also showed that this role depends on both the absolute quantity and the relative proportion of each fraction independently of the effects of their genetic variants. Coagulation time was shortened by $\alpha_{S 1}-\mathrm{CN}$ and $\kappa$-CN, greatly delayed by $\alpha_{S_{2}}-\mathrm{CN}$ (effects that were evident whether expressed as relative proportions or quantities), and not much affected by $\beta-\mathrm{CN}$. The overall result was that the total quantity of casein did not have an appreciable effect on RCT but the composition of it did. The potential asymptotical firmness of curd is greatly increased by the total casein content of the processed milk, due particularly to $\alpha_{\mathrm{S}^{-}} \mathrm{CN}$ and $\kappa-\mathrm{CN}$ and, to a lesser extent, $\beta-\mathrm{CN}$. On the other hand, $\alpha_{\mathrm{S}_{2}}$ $\mathrm{CN}$ and $\beta$-LG exert an unfavorable effect also when expressed as a proportion of the total casein content of milk. The protein fraction $\mathrm{k}-\mathrm{CN}$ is the only one with a concentration in milk having a large effect on the instant rate constants of both curd firming and curd syneresis. The information obtained from this study confirms that the technological behavior of bovine milk 

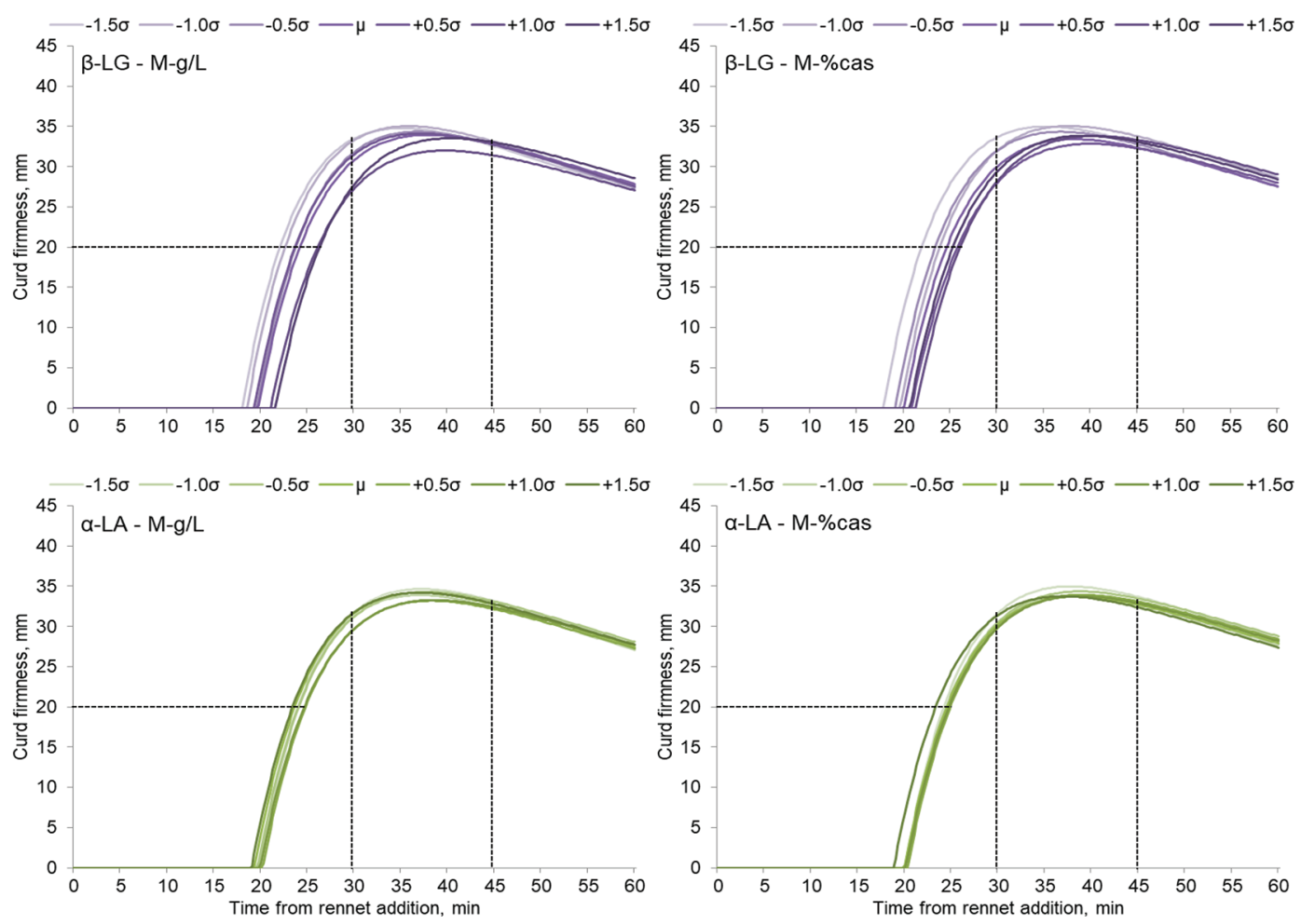

Figure 5. Pattern of curd firmness after rennet addition $\left(\mathrm{CF}_{\mathrm{t}}\right.$ modeling) of milk samples according to milk whey protein fractions ( $\beta$-LG and $\alpha-\mathrm{LA}$ ) content. For each fraction, results from the quantitative model (protein fractions expressed as grams per liter of milk; M-g/L) and from the qualitative model (protein fractions expressed as percentage of the total casein content; M-\%cas) are presented. The intersection of the horizontal black dashed line and of the vertical black dashed line at 30 and 45 min with firmness curves represents $\mathrm{k}_{20}$ (the time from coagulation to a curd firmness of $20 \mathrm{~mm}$ ), $\mathrm{a}_{30}$ (curd firmness 30 min after rennet addition), and $\mathrm{a}_{45}$ (curd firmness 45 min after rennet addition) of milk samples, respectively. For each whey protein fraction, the classes were constituted by half SD $(0.5 \sigma)$ of the whey protein fraction distribution, with the central class centering the average of the whey protein fraction.

can be highly influenced by protein fractions. These results could be useful in refining animal selection criteria to obtain more specific genetic improvement of the traits relevant to cheese production and can be used to improve quality payment criteria, provided that rapid and simple analytical tools become available in the near future.

\section{ACKNOWLEDGMENTS}

The authors thank the Autonomous Province of Trento (Italy), which provided the funds for the project, and the RISIB SMUPR (Potenziamento della rete di infrastrutture e supporto dell'innovazione biotecnologica) project no. 4145, which made available the instruments of the NIRS-Food Laboratory (Department of Agronomy, Food, Natural Resources, Animals and Environment, Legnaro, Italy). The authors gratefully acknowledge Valentina Bonfatti and Paolo Carnier (Department of Comparative Biomedicine and Food Science; University of Padova) for the analyses of the protein fractions with HPLC instrumentation.

\section{REFERENCES}

Annibaldi, S., G. Ferri, and R. Mora. 1977. Nuovi orientamenti nella valutazione tecnica del latte: Tipizzazione lattodinamografica. Sci. Tec. Latt.-Casearia 28:115-126.

Bittante, G. 2011. Modeling rennet coagulation time and curd firmness of milk. J. Dairy Sci. 94:5821-5832. https://doi.org/10.3168/ jds.2011-4514.

Bittante, G., C. Cipolat-Gotet, F. Malchiodi, E. Sturaro, F. Tagliapietra, S. Schiavon, and A. Cecchinato. 2015. Effect of dairy farming system, herd, season, parity, and days in milk on modeling of the coagulation, curd firming, and syneresis of bovine milk. J. Dairy Sci. 98:2759-2774. https://doi.org/10.3168/jds.2014-8909.

Bittante, G., B. Contiero, and A. Cecchinato. 2013. Prolonged observation and modelling of milk coagulation, curd firming, and syneresis. Int. Dairy J. 29:115-123. https://doi.org/10.1016/j.idairyj .2012 .10 .007 .

Bittante, G., M. Penasa, and A. Cecchinato. 2012. Invited review: Genetics and modeling of milk coagulation properties. J. Dairy Sci. 95:6843-6870. https://doi.org/10.3168/jds.2012-5507.

Bonfatti, V., A. Cecchinato, L. Gallo, A. Blasco, and P. Carnier. 2011 Genetic analysis of detailed milk protein composition and coagulation properties in Simmental cattle. J. Dairy Sci. https://doi.org/ 10.3168/jds.2011-4297.

Bonfatti, V., G. Di Martino, A. Cecchinato, L. Degano, and P. Carnier. 2010. Effects of $\beta$ - $\kappa$-casein (CSN2-CSN3) haplotypes, $\beta$-lactoglobulin (BLG) genotypes, and detailed protein composition on coagulation properties of individual milk of Simmental cows. J. Dairy Sci. 93:3809-3817. https://doi.org/10.3168/jds.2009 -2779 . 
Bonfatti, V., L. Grigoletto, A. Cecchinato, L. Gallo, and P. Carnier. 2008. Validation of a new reversed-phase high-performance liquid chromatography method for separation and quantification of bovine milk protein genetic variants. J. Chromatogr. A 1195:101106. https://doi.org/10.1016/j.chroma.2008.04.075.

Caroli, A. M., S. Chessa, and G. J. Erhardt. 2009. Invited review: Milk protein polymorphisms in cattle: Effect on animal breeding and human nutrition. J. Dairy Sci. 92:5335-5352. https://doi.org/10 $.3168 /$ jds.2009-2461.

Cipolat-Gotet, C., A. Cecchinato, M. De Marchi, and G. Bittante. 2013. Factors affecting variation of different measures of cheese yield and milk nutrient recovery from an individual model cheesemanufacturing process. J. Dairy Sci. 96:7952-7965.

Cipolat-Gotet, C., A. Cecchinato, M. De Marchi, M. Penasa, and G. Bittante. 2012. Comparison between mechanical and near-infrared methods for assessing coagulation properties of bovine milk. J. Dairy Sci. 95:6806-6819. https://doi.org/10.3168/jds.2012-5551.

Cipolat-Gotet, C., A. Cecchinato, M. Malacarne, G. Bittante, and A. Summer. 2018. Variations in milk protein fractions affect the efficiency of the cheese-making process. J. Dairy Sci. 101:8788-8804.

Dadousis, C., C. Cipolat-Gotet, G. Bittante, and A. Cecchinato. 2018. Inferring genetic parameters on latent variables underlying milk yield and quality, protein composition, curd firmness and cheesemaking traits in dairy cattle. Animal 12:224-231. https://doi.org/ 10.1017/S1751731117001616.

Dadousis, C., S. Pegolo, G. J. M. Rosa, G. Bittante, and A. Cecchinato. 2017. Genome-wide association and pathway-based analysis using latent variables related to milk protein composition and cheesemaking traits in dairy cattle. J. Dairy Sci. 100:9085-9102. https://doi.org/10.3168/jds.2017-13219.

Dalgleish, D. G. 1993. Bovine milk protein properties and the manufacturing quality of milk. Livest. Prod. Sci. 35:75-93.

De Roos, A. L., T. J. Geurts, and P. Walstra. 2000. The association of chymosin with artificial casein micelles. Int. Dairy J. 10:225-232. https://doi.org/10.1016/S0958-6946(00)00050-9.

Dunnewind, B., A. L. De Roos, and T. J. Geurts. 1996. Association of chymosin with caseins in solution. Ned. melk en Zuiveltijdschr. 50:121-133.

Fox, R. E. 2003. Milk proteins: General and historical aspects. Pages 1-48 in Advanced Dairy Chemistry. Vol. 1A: Proteins: Basic Aspects. 3rd ed. P. F. Fox and P. L. H. McSweeney, ed. Springer, New York, NY.

Guinee, T. P. 2003. Role of protein in cheese and cheese products. Pages 1,083-1,159 in Advanced Dairy Chemistry. Vol. 1B: Proteins: Basic Aspects. 3rd ed. P. F. Fox and P. L. H. McSweeney, ed. Springer, New York, NY.

Heck, J. M. L., A. Schennink, H. J. F. van Valenberg, H. Bovenhuis, M. H. P. W. Visker, J. A. M. van Arendonk, and A. C. M. van Hooijdonk. 2009. Effects of milk protein variants on the protein composition of bovine milk. J. Dairy Sci. 92:1192-1202. https:// doi.org/10.3168/jds.2008-1208.

Ikonen, T., K. Ahlfors, R. Kempe, M. Ojala, and O. Ruottinen. 1999. Genetic parameters for the milk coagulation properties and prevalence of noncoagulating milk in Finnish dairy cows. J. Dairy Sci. 82:205-214.

Ikonen, T., S. Morri, A.-M. Tyrisevä, O. Ruottinen, and M. Ojala. 2004. Genetic and phenotypic correlations between milk coagulation properties, milk production traits, somatic cell count, casein content, and pH of milk. J. Dairy Sci. 87:458-467. https://doi.org/ 10.3168/jds.S0022-0302(04)73185-9.

ISO. 2002. Dried milk, dried ice-mixes and processed cheese-Determination of lactose content-Part 1: Enzymatic method utilizing the galactose moiety of the lactose (ISO 5765-1/IDF 79-1). International Organization for Standardization, Geneva, Switzerland.

ISO. 2004. Milk-Determination of casein-nitrogen content-Part 1: Indirect method (ISO 17997-1/IDF 29). International Organization for Standardization, Geneva, Switzerland.

ISO. 2010. Milk-Determination of fat content-Gravimetric method (ISO 1211/IDF 1). International Organization for Standardization, Geneva, Switzerland.
ISO. 2014. Milk and milk products-Determination of nitrogen content-Part 1: Kjeldahl principle and crude protein calculation (ISO 8968-1/IDF 20-1). International Organization for Standardization, Geneva, Switzerland.

Jensen, H. B., J. W. Holland, N. A. Poulsen, and L. B. Larsen. 2012a. Milk protein genetic variants and isoforms identified in bovine milk representing extremes in coagulation properties. J. Dairy Sci. 95:2891-2903. https://doi.org/10.3168/jds.2012-5346.

Jensen, H. B., N. A. Poulsen, K. K. Andersen, M. Hammershøj, H. D. Poulsen, and L. B. Larsen. 2012b. Distinct composition of bovine milk from Jersey and Holstein-Friesian cows with good, poor, or noncoagulation properties as reflected in protein genetic variants and isoforms. J. Dairy Sci. 95:6905-6917. https://doi.org/10.3168/ jds.2012-5675.

Jõudu, I., M. Henno, T. Kaart, T. Püssa, and O. Kärt. 2008. The effect of milk protein contents on the rennet coagulation properties of milk from individual dairy cows. Int. Dairy J. 18:964-967. https: //doi.org/10.1016/j.idairyj.2008.02.002.

Ketto, I. A., T. M. Knutsen, J. Øyaas, B. Heringstad, T. Ådnøy, T. G. Devold, and S. B. Skeie. 2017. Effects of milk protein polymorphism and composition, casein micelle size and salt distribution on the milk coagulation properties in Norwegian Red cattle. Int. Dairy J. 70:55-64. https://doi.org/10.1016/j.idairyj.2016.10.010.

Marziali, S., and K. F. Ng-Kwai-Hang. 1986. Effects of milk composition and genetic polymorphism on coagulation properties of milk. J. Dairy Sci. 69:1793-1798. https://doi.org/10.3168/jds.S0022 -0302(86)80603-8.

McMahon, D. J., and R. J. Brown. 1982. Evaluation of formagraph for comparing rennet solutions. J. Dairy Sci. 65:1639-1642.

Pegolo, S., N. Mach, Y. Ramayo-Caldas, S. Schiavon, G. Bittante, and A. Cecchinato. 2018. Integration of GWAS, pathway and network analyses reveals novel mechanistic insights into the synthesis of milk proteins in dairy cows. Sci. Rep. 8:566. https://doi.org/10 $.1038 / \mathrm{s} 41598-017-18916-4$.

Politis, I., and K. F. Ng-Kwai-Hang. 1988. Effects of somatic cell counts and milk composition on the coagulating properties of milk. J. Dairy Sci. 71:1740-1746. https://doi.org/10.3168/jds.S0022 -0302(88)79740-4.

Poulsen, N. A., M. Glantz, A. K. Rosengaard, M. Paulsson, and L. B. Larsen. 2017. Comparison of milk protein composition and rennet coagulation properties in native Swedish dairy cow breeds and high-yielding Swedish Red cows. J. Dairy Sci. 100:8722-8734. https://doi.org/10.3168/jds.2017-12920.

Schaar, J., B. Hansson, and H.-E. Pettersson. 1985. Effects of genetic variants of $\kappa$-casein and $\beta$-lactoglobulin on cheesemaking. J. Dairy Res. 52:429-437.

St-Gelais, D., and S. Haché. 2005. Effect of $\beta$-casein concentration in cheese milk on rennet coagulation properties, cheese composition and cheese ripening. Food Res. Int. 38:523-531. https://doi.org/10 .1016/j.foodres.2004.11.006.

Stocco, G., C. Cipolat-Gotet, A. Cecchinato, L. Calamari, and G. Bittante. 2015. Milk skimming, heating, acidification, lysozyme, and rennet affect the pattern, repeatability, and predictability of milk coagulation properties and of curd-firming model parameters: A case study of Grana Padano. J. Dairy Sci. 98:5052-5067. https:// doi.org/10.3168/jds.2014-9146.

Tyrisevä, A.-M., T. Vahlsten, O. Ruottinen, and M. Ojala. 2004. Noncoagulation of milk in Finnish Ayrshire and Holstein-Friesian cows and effect of herds on milk coagulation ability. J. Dairy Sci. 87:3958-3966.

Vallas, M., H. Bovenhuis, T. Kaart, K. Parna, H. Kiiman, and E. Pärna. 2010. Genetic parameters for milk coagulation properties in Estonian Holstein cows. J. Dairy Sci. 93:3789-3796.

Wedholm, A., L. B. Larsen, H. Lindmark-Månsson, A. H. Karlsson, and A. Andrén. 2006. Effect of protein composition on the cheesemaking properties of milk from individual dairy cows. J. Dairy Sci. 89:3296-3305 